\title{
Relato de caso de raiva humana após exumação no Município de São Paulo
}

\author{
Case report of post-exhumation human rabies in the city of São Paulo
}

Instituto Pasteur. Secretaria de Estado da Saúde de São Paulo

\section{INTRODUÇÃO}

Em 17 de maio de 2004, um dos médicos do Instituto Pasteur atendeu a uma mulher, por telefone, que relatava o óbito do esposo da sua empregada, levantando a hipótese de que poderia ter falecido de raiva, apesar de o mesmo já ter sido enterrado, com outra causa de óbito. Foi solicitado, então, que a viúva comparecesse ao Ambulatório do Instituto, o que ocorreu no dia seguinte. Frente ao histórico do caso relatado e considerando que a vítima havia sido atendida em três serviços de saúde, buscou-se obter maiores informações sobre os sinais, sintomas e exames subsidiários.

Com o que foi apurado e considerando a hipótese de raiva, foram iniciados os procedimentos para a exumação, que aconteceram em três âmbitos:

1. Familiar: contato com a viúva, para que a família permitisse a exumação;

2. Legal: para obtenção da autorização foram contatadas a Chefia de Gabinete e Consultoria Jurídica da Secretaria Estadual da Saúde, Sub-Procuradoria da área do Contencioso e Centro de Vigilância Sanitária, assim como o levantamento da legislação;

3. Política: foram contatados o Programa Nacional de Controle da Raiva, Gerência de Zoonoses, Secretaria de Vigilância em Saúde, do Ministério da Saúde, e a área correspondente em Minas Gerais, uma que a provável transmissão pode ter ocorrido em município mineiro.

Somente no dia $3 / 6$ foi obtida a autorização para exumação, sendo então tomadas providências junto aos vários escalões da área de cemitérios do município de São Paulo. No dia 4, às 16 horas, procedeu-se à exumação.

\section{INFORMAÇÕ ES SOBRE O CASO}

As informações foram obtidas após o óbito, por intermédio de contatos com familiares do paciente, profissionais de saúde que fizeram o atendimento e da
Vigilância Epidemiológica de Minas Gerais, que se deslocaram ao local da provável transmissão.

Dados gerais: J.M.R., sexo masculino, cor branca, torneiro mecânico (sem carteira de trabalho assinada, trabalhando como pedreiro), 62 anos, natural de Carbonita (MG), residente em Francisco Morato, Região Metropolitana da Grande São Paulo; casado (segundo casamento); pai de cinco filhos.

Antecedentes mórbidos: não era portador de hipertensão arterial e/ou diabetes. Não tinha qualquer outra patologia. Recebeu vacina contra influenza em 27/4.

Histórico: o paciente esteve em Carbonita e arredores durante um mês, no período compreendido entre 7 de fevereiro e a primeira semana de março. Provavelmente no dia 28/2 foi mordido por um morcego no tornozelo direito (região maleolar externa), por volta da 20h30, quando se encontrava jogando baralho com amigos e primos, que sugeriram que procurasse um serviço da saúde, o que não foi acatado.

Por volta do dia 17/4, após cerca de 50 dias, queixou-se com a esposa de "dormência" na perna direita, suspeitando que o sintoma tivesse relação com a mordida do morcego. O sintoma persistiu e após uma semana (24/4) o paciente apresentou dor de cabeça contínua. Evoluiu com dor na perna, que ia até a panturrilha, e aumento da dor de cabeça. No dia $27 / 4$, procurou o Hospital de Francisco Morato, onde foram receitados analgésico e antiinflamatório. Achava que esse estado estivesse relacionado com a vacina contra influenza.

A pressão sanguínea estava normal. Referiu ter melhorado um pouco da dor de cabeça, mas, como a dor na perna havia aumentado, procurou o Hospital de Várzea Paulista (Amec), em 30/4, onde foi aplicada injeção de antiinflamatório. No dia $1 / 5$, com a evolução do quadro no membro inferior direito, procurou novamente esse hospital; apresentou quadro "convulsivo" e foi, então, internado. 
Começou a apresentar pigarro, soluços, náuseas, dificuldade de engolir, a saliva ficava na boca e os lábios secos. Segundo informação médica, o paciente estava subfebril (ao redor de $37^{\circ} \mathrm{C}$ a $37,5^{\circ} \mathrm{C}$ ). Evoluiu com a apresentação de paralisia no membro superior esquerdo, assim como na perna esquerda, sendo aventada a hipótese de Acidente Vascular Cerebral.

Foi encaminhado no dia 2/5 para o Hospital São Vicente de Paula, em Jundiaí, SP, para realizar tomografia computadorizada, retornando ao Várzea Paulista. Nos dias 2 e 3 continuou apresentando "convulsões" e "tremores", sem perda da consciência, intercalando períodos de agitação e calma. Nestes últimos, conversava com a esposa e outros familiares, que referiram que o paciente apresentava alucinações (via um jardim com flores).

Já no dia 2 os médicos do hospital onde se encontrava internado comunicaram à esposa que o paciente tinha tido um "derrame" e que o quadro era irreversível. Foi a óbito no dia 4/5.

\section{O BSERVAÇÕ ES}

1. O paciente relatou aos médicos a agressão pelo morcego.

2. Na região de Carbonita há registro de casos de raiva herbívoros domésticos (bovinos, eqüinos etc.), o que comprova a existência da circulação do vírus.

\section{CONCLUSÃO}

Conforme já referido, a exumação foi realizada em 4/ 6, um mês após o óbito. Foi aberta a caixa craniana e coletado material que já se encontrava gelatinoso; e, pelo estado de decomposição, não foi possível identificar as estruturas (cérebro, cerebelo, bulbo, etc.) do Sistema Nervoso Central (SNC).

Habitualmente, são realizadas duas provas para o diagnóstico da raiva: Imunofluorescência Direta e isolamento viral em camundongo ou cultura de células de Neuroblastoma murino. A partir do isolamento viral é que se realiza a Tipificação Antigênica por Anticorpos Monoclonais. Foi preparado, para Imunofluorescência Direta, um número maior de lâminas que o habitual, sendo confirmado em $8 / 6$ o diagnóstico laboratorial da raiva humana.

Neste caso, a Prova Biológica foi impossibilitada devido à contaminação de bactérias, e, conseqüentemente, a Tipificação Antigênica. Foi feito o PCR (Reação de Polimerase em Cadeia), que confirmou o resultado de raiva e é etapa que antecede a Tipificação Genética (Seqüenciamento Genético), a ser realizada.

\section{CONSID ERAÇÕ ES}

Este relato deve servir de alerta aos profissionais de saúde para casos de raiva que podem estar ocorrendo em todo País, inclusive no Estado de São Paulo. Alguns pontos devem ser ressaltados:

- Os profissionais da saúde não aventam a hipótese diagnóstica de raiva, esperando sinais e sintomas exuberantes de livros e textos científicos, e os médicos formados em nosso meio a partir da década de 1980, provavelmente, nunca viram um óbito pela doença.

- A sintomatologia dos casos de raiva humana, por variantes do vírus da raiva que não são próprias do cão, pode não ser mais a clássica, com hidrofobia e aerofobia;

- A hipótese de ocorrência de raiva deve ser considerada nos quadros neurológicos de encefalite, com sinais e sintomas clássicos da doença e, também, naqueles que apresentem prurido (geralmente no local da agressão) e/ou sensação de parestesia ("dormência" ou "formigamento"), paresias e paralisias.

- A presença de outros sinais e sintomas, como tremores ou convulsões, dor de garganta ou dificuldade de deglutição, sinais de desidratação com acúmulo de saliva na boca, rouquidão, soluços, pigarro, náuseas, vômitos, diarréia e febre baixa, devem servir também de alerta como sugestivos de raiva.

- Qualquer espécie de morcego pode transmitir a raiva. Em 2003, no Estado de São Paulo foram registrados mais de 100 casos de raiva em morcegos, sendo a grande maioria de espécies não hematófagas (95\%).

- Os morcegos hematófagos provocam mordeduras para se alimentar e outras espécies de morcegos não hematófagas podem agredir, numa atitude defensiva ao se sentirem ameaçados, como, por exemplo, ao serem manuseados ou pisoteados.

- O encontro de morcegos caídos no chão, voando durante o dia, que se chocam contra muros ou paredes, são sinais indicativos de raiva, e devem ser encaminhados para laboratório de forma segura.

- Quando uma doença como a raiva atinge o "status" de controle, é necessário que se estabeleça uma maior vigilância em animais e humanos.

- Os profissionais de saúde devem lembrar que a raiva pode ser transmitida por outros mamíferos, como morcegos, animais silvestres terrestres e do meio rural, e não somente por cães e gatos.

- O diagnóstico ante-mortem dos casos de raiva é dificultoso, demorado e mesmo quando negativo não descarta a raiva. Como a doença é fatal, é importante que sejam coletados fragmentos do SNC (nunca colocar em formol) pós-mortem, para o diagnóstico laboratorial.

- Nos casos em que existe histórico epidemiológico e quadro clínico compatível com raiva, mesmo que a pessoa já tenha falecido, devem ser efetuados todos os esforços para a elucidação do caso, incluindo a exumação. 